Relations industrielles

Industrial Relations

\title{
Kent, Ronald C., Sara Markham, David R. Roediger, and Herbert Shapiro, eds, Culture, Gender, Race and U.S. Labor History
}

\section{Charles J. McCollester}

Volume 49, numéro 4, 1994

Syndicats et restructuration économique

Unions and Economic Restructuring

URI : https://id.erudit.org/iderudit/050984ar

DOI : https://doi.org/10.7202/050984ar

Aller au sommaire du numéro

Éditeur(s)

Département des relations industrielles de l'Université Laval

ISSN

0034-379X (imprimé)

1703-8138 (numérique)

Découvrir la revue

Citer ce compte rendu

McCollester, C. J. (1994). Compte rendu de [Kent, Ronald C., Sara Markham, David R. Roediger, and Herbert Shapiro, eds, Culture, Gender, Race and U.S. Labor History]. Relations industrielles / Industrial Relations, 49(4), 869-871. https://doi.org/10.7202/050984ar

Tous droits réservés @ C Département des relations industrielles de l'Université Laval, 1994
Ce document est protégé par la loi sur le droit d'auteur. L'utilisation des services d'Érudit (y compris la reproduction) est assujettie à sa politique d'utilisation que vous pouvez consulter en ligne.

https://apropos.erudit.org/fr/usagers/politique-dutilisation/ 
Culture, Gender, Race, and U.S. Labor History, by Ronald C. KENT, Sara MAR KHAM, David R. RoEdiger, and Herbert ShapIRo (eds), Westport, Conn., Greenwood Publishing Group, 1993, 215 p., ISSN 0886-8239.

This volume collects eleven papers which were presented at a conference held in Madison Wisconsin in 1990 . The conference sponsored by the Wisconsin Historical Society and the International Labor History Association invited contributions on a broad range of subjects impacting U.S. labor history including culture, gender and race.

The common thread which unites these studies is that they generally treat dissident movements (or figures) which have usually been found at the margins of traditional labor history. By and large, they reflect the efforts of recent scholarship to expand the field of labor history to consider the complexities of the social context that helped define efforts at labor organization. The subjects chosen lie outside the concerns of traditional institutional historians as well as those undertaken by more recent students of workplace relations.

Four of the studies are biographical:

The first, by Robert R. Montgomery, deals with the career of George Edwin Marshall from Massachusetts who between 1863 and 1890 was "a pivotal figure in linking native labor reformers, seeking a theory of labor organization, with immigrant socialists seeking to apply Marx's theory to US conditions." A pioneer in the eight hour day struggle, he helped organize the International Labor Union which attempted to forge a single centralized organization of skilled and unskilled labor in the aftermath of the great railroad upheaval of 1877 . He was a defender of the struggle for shorter hours and for trade unions as the road to socialism.

The second, by Jennifer L. Bosch studies the contribution of Ellen Gates Starr, a cofounder with Jane Addams of Chicago's Hull House. A follower of John Ruskin and William Morris, she reacted against the extreme poverty of Chicago's working class as well as with repugnance over the competitive nature of capitalism which forced workers "to make and buy useless and ugly things." She became an ardent supporter for workers on strike in Chicago between 1896 and 1915 and was a charter member of the Women's Trade Union League.

The third sketch by Horst Ihde examines the work experience behind a famous volume of American literature, Richard Henry Dana's Two Years Before the Mast. A Harvard student when he signed on as a sailor aboard a small sailing vessel bound for California, Dana remained an advocate for the human rights of sailors his entire career. The description of the harsh system of labor relations (including flogging) imposed on working sailors clearly distinguished Dana's account from the literary genre of romantic travel narratives that were popular in his day.

The fourth biographical entry is a memoir by Morris U. Schappes which tells how Philip S. Foner and more than forty other employees (including himself) of the City College of New York were fired as a result of the investigations of the Rapp-Coudert Committee of the New York State Legislature charged with ferreting out "subversive activities". Since this event predated the activities of Joe McCarthy by more than eight years, it serves to remind us of the long history of red-baiting in American history which 
goes back at least to the 1870 's. The story has academic heroes as well as villains and ultimately the College apologized to the victims in 1981 .

The book contains two very interesting articles on Black labor history during the Reconstruction period:

The first, by Eric Foner, uncovers the discussions concerning labor relations at Black labor conventions held during the Reconstruction period. Statewide labor conventions were held in Georgia, South Carolina, and Alabama from 1869 to 1872. Central to their concerns was the resistance generated by the surviving plantation-dominated economy to the Black workers' search for economic independence. The black struggle focused on the assertion that they were renters "obligated to pay a share to the landowner at the end of the year, but otherwise free from outside supervision." On the other hand, the planters insisted that freed slaves were employees who received a share of the crop as a wage and thus could be directed to labor in whatever way the landowner desired.

The study by Elizabeth Ann Sharpe about Mississippi plantation labor also places the struggle for control of southern agricultural production at center stage. The imposition on the southern freedman of a contract system analogous to the northern wage labor system destroyed the possibility of free land ownership for the ex-slaves. Most interestingly, the author describes a brief experiment on the Davis Bend plantation in Mississippi where land was leased to freed slaves which blossomed briefly into a rare experience of economic democracy.

Two studies deal with dissident movements on the left of the labor movement:

Allen Ruff's study of the Proletarian Party sheds light on the early history of Communism in the U.S. The Proletarian Party was based in Michigan where its attacks on the reformism of the Socialist Party led to its successful capture of control over the state Socialist Party by 1918 . Once in power, they threatened the expulsion of any party member who supported the more conservative national Socialist Party leadership and they adopted positions overtly hostile to religion. However, when they participated in the founding convention of the Communist Party of America, the Michigan group found themselves in opposition to "minority action" viewpoint of the foreign language federations that dominated the new party. Urging broad working-class education and work within the trade unions, the Michigan group found itself becoming the first tendency to be purged by the young Communist party.

Rochelle Gatlin's study of the Union W.A.G.E. (Women's Alliance to Gain Equality) organization considers a group centered in San Francisco that attempted to struggle on two fronts: attacking sexism in unions and workplaces while simultaneously attempting to make the concerns of working class women central to the women's movement. It situated itself to the left of the Coalition for Labor Union Women (CLUW) and could never fully resolve whether it advocated established or independent unions. Similarly, questions like the relative importance of "personal politics", issues like sexuality and family vis-à-vis economic and workplace struggles, etc. were a subject of intense debate. After eleven years the organization folded in 1982.

Finally, three papers in this collection touch on the history of the Socialist Party in the period of its decline from 1919 to 1932 : 
The first, by John Sherman describes the Socialist Party's amnesty campaigns on behalf of its revered party leader Eugene V. Debs and other persons arrested for anti-war activities. The party was politically weakened by its principled anti-war stance, divided internally as the proponents of the Bolshevik model of a highly disciplined revolutionary party split away, and subjected to an anti-red attack which was raised to a fever pitch during the great steel strike of 1919. In this context, the Socialists rallied behind their beloved leader while attempting to raise the issue of all political prisoners. The ironic fact is that it took the election of arch conservative Republican Warren G. Harding to obtain a presidential pardon for two dozen prisoners including Debs. Meanwhile the noble liberal, Woodrow Wilson carried hostility toward Debs to his grave.

The Wilson-Debs exchange is worth repeating:

"I will never consent to the pardon of this man.... While the flower of American youth was pouring out its blood to vindicate the cause of civilization, this man, Debs, stood behind the lines, sniping, attacking, and denouncing them." [Woodrow Wilson]

"It is he not I who deserves a pardon. If I had it in my power I would give him the pardon that would set him free. Woodrow Wilson is an exile from the hearts of his people. The betrayal of his ideals make him the most pathetic figure in the world." [Eugene V. Debs]

The paper by Nathan Godfried is a very interesting look at the unsuccessful effort of the Socialist Party to break the corporate monopoly over radio broadcasting from 1926-1932. Despite the Socialist Party's decline it attempted to revive its fortunes by a two-pronged radio strategy. First, it ran at great cost and subject to much harassment by the Federal Radio Commission, a radio station WEVD (for Eugene Victor Debs) in New York City. While the FRC attacked the station as a weak "special interest" station, the Socialists defended their multi-ethnic and working class programming on a basis of free speech and minority rights. The second avenue that the party explored was token exposure through NBC that the author claims was simply a method for "the capitalist owners of radio to legitimize their power.'

The final study by Gloria Garrett Samson on worker's education programs in the 1920's examines such pioneering efforts as the Boston Trade Union College, Commonwealth College and Brookwood College. Workers education has always had a somewhat difficult relationship to the institutional union movement because it could and indeed often did lead to the rise of new union leadership. However, the explicitly class struggle orientation of these early efforts was transformed to a distinctly reformist character as worker education became "Labor Studies"' and was subsumed into institutions of higher education "where curriculum and faculty could be controlled."

In conclusion, the articles included in this volume provide a rich mix of studies on U.S. labor history and illustrate the wide range of concerns exhibited by contemporary labor scholars.

Charles J. MCCOLLESTER

Indiana University of Pennsylvania 